\title{
Block Copolymers of Highly Isotactic Polypropylene via Controlled Ziegler- Natta Polymerization
}

\author{
Vincenzo Busico*, Roberta Cipullo, Nic Friederichs”, Sara Ronca, Giovanni Talarico, Maria Togrou, \\ Bing Wang \\ Dipartimento di Chimica, Università di Napoli "Federico II" - Via Cintia - 80126 Naples (Italy) \\ ${ }^{\#}$ SABIC EuroPetrochemicals - Research \& Development Centre - P.O. Box 319-6160 AH Geleen (The Netherlands)
}

\section{Supporting Information}

\section{Experimental section}

\section{Preparation of complexes 3-5}

All ligands were prepared by reacting N,N'-dimethyl-ethylenediamine with formaldehyde and the appropriate phenol, as described in the literature..$^{5}$ 2-(1-Adamantyl)-4-methylphenol (for complex 3) was purchased from Aldrich and used as received. 2-(9-Anthracenyl)-4-methylphenol (for complex 4) and 2-cumyl-4-methylphenol (for complex 5), which are not commercially available, were prepared on purpose as described below.

- Synthesis of 2-(9-anthracenyl)-4-methylphenol (Scheme S1 and following procedure)

Scheme S1<smiles>COc1ccc(C)cc1Br</smiles>

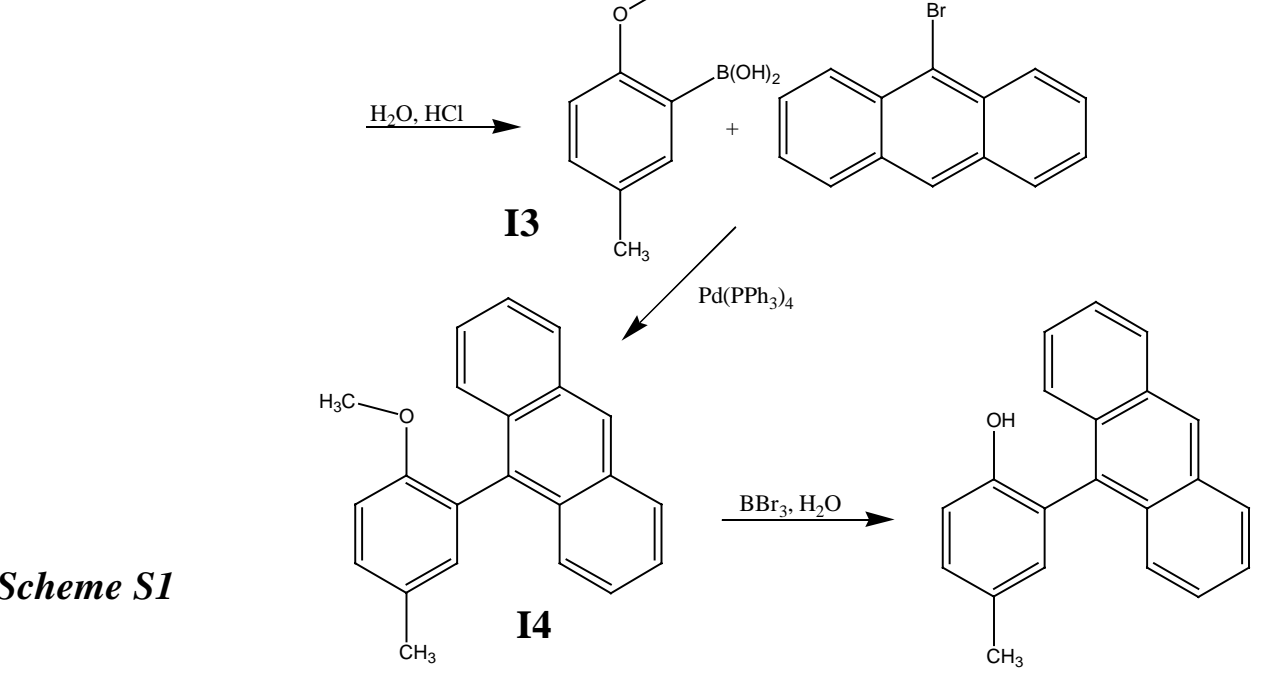


$2 \mathrm{~g}$ of $\mathrm{Mg}$ turnings were weighted in a three-necked, round-bottomed $250 \mathrm{~mL}$ flask equipped with a nitrogen inlet-outlet, a reflux condenser and a cap, then $60 \mathrm{~mL}$ of dry diethylether and 4 crystals of $\mathrm{I}_{2}$ were added. The solution became orange: when the color faded out, $4.5 \mathrm{~mL}(0.031 \mathrm{~mol})$ of $4-$ methyl-2-bromoanisole were syringed in, drop by drop. The solution was kept at room temperature under stirring overnight, after which it was carefully decanted into a $250 \mathrm{~mL}$ Schlenk flask under $\mathrm{N}_{2}$. After chilling to $-80{ }^{\circ} \mathrm{C}$ in an acetone/liquid nitrogen bath, $19 \mathrm{~mL}(0.17 \mathrm{~mol})$ of trimethylborate were added. The bath was removed, the reaction mixture allowed to warm up to room temperature, and stirred magnetically for additional 4 hours. $\mathrm{HCl}(\mathrm{aq}, 10 \% \mathrm{w} / \mathrm{w})$ was then added to the white paste formed: the color gradually turned to yellow. The organic layer was separated, and the water layer extracted with diethylether. The organic fractions were collected, washed with water and dried over anhydrous $\mathrm{MgSO}_{4}$. The ether was finally evaporated, giving $3.6 \mathrm{~g}(0.022 \mathrm{~mol})$ of $\mathbf{I 3}$ in the form of a yellow powder (yield: $71 \%$ referred to the starting anisole).

${ }^{1} \mathrm{H} \mathrm{NMR}\left(\mathrm{CDCl}_{3}, \mathrm{ppm}\right): \delta 2.21\left(s, 3 \mathrm{H}, \mathrm{CH}_{3}\right), 3.80\left(s, 3 \mathrm{H}, \mathrm{OCH}_{3}\right), 6.5\left(\right.$ broad, $\left.2 \mathrm{H}, \mathrm{B}(\mathrm{OH})_{2}\right), 6.72(d$, $1 \mathrm{H}, \mathrm{Ar}), 7.13(d, 1 \mathrm{H}, \mathrm{Ar}), 7.58(s, 1 \mathrm{H}, \mathrm{Ar})$.

$3.6 \mathrm{~g}(0.022 \mathrm{~mol})$ of $\mathbf{I 3}, 5 \mathrm{~g}(0.019 \mathrm{~mol})$ of 9-bromoanthracene and $8.2 \mathrm{~g}(0.039 \mathrm{~mol})$ of potassium phosphate were weighted in a $200 \mathrm{~mL}$ Schlenk flask, then $80 \mathrm{~mL}$ of tetrahydrofurane, $10 \mathrm{ml}$ of $\mathrm{H}_{2} \mathrm{O}$ and $2.4 \mathrm{~g}(2 \mathrm{mmol})$ of $\mathrm{Pd}\left(\mathrm{PPh}_{3}\right)_{4}$ were added. The Schlenk was purged with nitrogen, fitted with a reflux condenser and kept under reflux for 1 day. $3 \mathrm{~g}(2.6 \mathrm{mmol})$ more of $\mathrm{Pd}\left(\mathrm{PPh}_{3}\right)_{4}$ were added, and the dark-green suspension refluxed for additional 7 hours, cooled to room temperature and poured into $150 \mathrm{~mL}$ of $\mathrm{HCl}$ (aq, 5\%). The organic layer was separated, and the water layer extracted with $2 \times 50 \mathrm{~mL}$ diethyl ether; the combined organic layers were dried with anhydrous $\mathrm{MgSO}_{4}$ and the ether evaporated, to give $\mathbf{I} 4$ as a yellow powder. This was washed with diethyl ether/pentane, and dried; yield, $5.4 \mathrm{~g}(0.018 \mathrm{~mol} ; 82 \%$ referred to $\mathbf{I 3})$.

${ }^{1} \mathrm{H} \mathrm{NMR}\left(\mathrm{CDCl}_{3}, \mathrm{ppm}\right): \delta 2.28\left(s, 3 \mathrm{H}, \mathrm{CH}_{3}\right), 3.47\left(s, 3 \mathrm{H}, \mathrm{OCH}_{3}\right), 6.95(t, 2 \mathrm{H}, \mathrm{Ar}), 7.2-7.26(m$, $\mathrm{Ar}), 7.34$ ( $t, 2 \mathrm{H}, \mathrm{Ar}), 7.54$ ( $d, 2 \mathrm{H}, \mathrm{Ar}), 7.93(d, 2 \mathrm{H}, \mathrm{Ar}), 8.37$ (s, 1H, Ar).

In a $250 \mathrm{~mL}$ round-bottomed flask, $5.4 \mathrm{~g}(0.018 \mathrm{~mol})$ of $\mathbf{I} 4$ were dissolved in $150 \mathrm{~mL}$ of dichloromethane (previously dried over molecular sieves), and chilled to $-80{ }^{\circ} \mathrm{C}$ in an acetone/liquid nitrogen bath. A solution of $32 \mathrm{~mL}(0.032 \mathrm{~mol})$ of boron tribromide $(1.0 \mathrm{M}$ in dichloromethane) was then slowly added by means of a syringe. The bath was removed, and the system allowed to warm to room temperature and left under stirring for 4 more hours. The reaction mixture was poured into $500 \mathrm{~mL}$ of a saturated aqueous solution of sodium sulfate, kept under stirring for $30 \mathrm{~min}$, then added with $\mathrm{HCl}$ (aq, 10\%) down to $\mathrm{pH} 1$. The organic layer was separated, the water layer washed twice with diethylether, and the organic phases collected, dried over $\mathrm{MgSO}_{4}$ and evaporated to give a brown syrup. This was diluted in $200 \mathrm{~mL}$ of diethylether, and kept under stirring overnight. After filtering to separate any unreacted solid, the ether was evaporated to give $5.0 \mathrm{~g}$ of the desired 2-(9-anthracenyl)-4-methylphenol (yield: $98 \%$ referred to I4). This was finally washed with methanol and pentane, and dried.

${ }^{1} \mathrm{H} \mathrm{NMR}\left(\mathrm{CDCl}_{3}, \mathrm{ppm}\right): \delta 2.39\left(s, 3 \mathrm{H}, \mathrm{CH}_{3}\right), 6.97(m, 2 \mathrm{H}, \mathrm{Ar}), 7.17(d, 1 \mathrm{H}, \mathrm{Ar}), 7.30-7.43(m, 4 \mathrm{H}$, $\operatorname{Ar}), 7.61(d, 2 \mathrm{H}, \mathrm{Ar}), 7.97(d, 2 \mathrm{H}, \mathrm{Ar}), 8.46(s, 1 \mathrm{H}, \mathrm{Ar})$.

\section{- Synthesis of 2-cumyl-4-methylphenol}

The synthesis was carried out according to: Rosevear, J.; Wilshire, J.F.K. Aust. J. Chem. 1985, 38, $1163.190 \mathrm{mg}(0.0010 \mathrm{~mol})$ of $p$-toluenesulfonic acid were added to $11.89 \mathrm{~g}(0.11 \mathrm{~mol})$ of $p$-cresol kept in an ice bath, under stirring. To the mixture, $13 \mathrm{~mL}(0.10 \mathrm{~mol})$ of $\alpha$-methylstyrene were added dropwise. The system was allowed to reach room temperature, then was heated at $45-50^{\circ} \mathrm{C}$ for $1 \mathrm{~h}$. Fractionation of the oily product in vacuum gave $12 \mathrm{~g}$ of 2-cumyl-4-methyl phenol (yield: 55\%).

${ }^{1} \mathrm{H}$ NMR $\left(\mathrm{CDCl}_{3}, \mathrm{ppm}\right): \delta 1.66\left(s, 6 \mathrm{H}, \mathrm{C}\left(\mathrm{CH}_{3}\right)_{2}\right), 2.37\left(s, 3 \mathrm{H}, \mathrm{CH}_{3}\right), 4.17(b s, 1 \mathrm{H}, \mathrm{OH}), 6.67(d, 1 \mathrm{H}$, Ar), 6.8-7.6 ( $m, 7 \mathrm{H}, \mathrm{Ar})$. 


\section{- Synthesis of the [ONNO] ligands}

The synthesis of the tetradentate [ONNO] ligands was performed as described in the literature, ${ }^{5}$ with minor changes. $5 \mathrm{mmol}$ of $\mathrm{N}, \mathrm{N}$ '-dimethyl-ethylenediamine (Aldrich), $10 \mathrm{mmol}$ of formaldehyde (Aldrich, 37\% solution in water), and $10 \mathrm{mmol}$ of the appropriate phenol were added to $30 \mathrm{~mL}$ of methanol and kept under reflux for 1-2 days. The solid appearing, which is the desired product, was filtered off, washed with cold methanol and dried in an oven, at $65{ }^{\circ} \mathrm{C}$ under vacuum for $3 \mathrm{~h}$. A second crop of product could be obtained by keeping the methanol solution in a fridge for several days. The total yield ranged from $15-20 \%$ (anthracenyl and adamantyl ligands) to $40 \%$ (cumyl ligand).

Adamantyl-substituted ligand: ${ }^{1} \mathrm{H}$ NMR (400 MHz, $\mathrm{C}_{6} \mathrm{D}_{6}, 300 \mathrm{~K}$, partly soluble): $\delta 1.75-1.93$ (m, $\left.18 \mathrm{H}, \mathrm{CH}_{3}, \mathrm{CH}_{2}\right), 2.14\left(\mathrm{~m}, 10 \mathrm{H}, \mathrm{CH}, \mathrm{CH}_{2}\right), 2.28\left(\mathrm{~s}, 6 \mathrm{H}, \mathrm{CH}_{3}\right), 2.42\left(\mathrm{~m}, 12 \mathrm{H}, \mathrm{CH}_{2}\right), 3.21(\mathrm{~s}, 4 \mathrm{H}$, $\left.\mathrm{NCH}_{2} \mathrm{Ar}\right), 6.54(d, 2 \mathrm{H}, \mathrm{Ar}), 7.10(d, 2 \mathrm{H}, \mathrm{Ar}), 10.66(b s, 2 \mathrm{H}, \mathrm{OH}) .{ }^{13} \mathrm{C} \mathrm{NMR}\left(100 \ldots \mathrm{MHz}, \mathrm{C}_{6} \mathrm{D}_{6}\right.$, $300 \mathrm{~K}$, partly soluble): $\delta 21.1\left(\mathrm{CH}_{3}\right), 29.6\left(\mathrm{CH}\right.$, adamantyl group), 37.2 ( $C_{\mathrm{ipso}}$, adamantyl group), $37.6\left(\mathrm{CH}_{2}\right.$, adamantyl group), $40.9\left(\mathrm{CH}_{2}\right.$, adamantyl group), $41.2\left(\mathrm{~N}-\mathrm{CH}_{3}\right), 53.7\left(\mathrm{NCH}_{2}\right), 62.2$ $\left(\mathrm{NCH}_{2} \mathrm{Ar}\right), 122.1\left(C_{\mathrm{ipso}}\right), 127.2(C-\mathrm{H}), 127.3(C-\mathrm{H}), 136.9\left(C_{\mathrm{ipso}}\right), 155.2\left(C_{\mathrm{ipso}}\right)$.

$\mathrm{C}_{40} \mathrm{H}_{56} \mathrm{~N}_{2} \mathrm{O}_{2}$ - Elemental analysis (calc/found, \%): C, 80.49/80.32; H, 9.46/9.35; N, 4.69/4.77.

Anthracenyl-substituted ligand: ${ }^{1} \mathrm{H} \mathrm{NMR}\left(400 \mathrm{MHz}, \mathrm{CDCl}_{3}, 300 \mathrm{~K}\right): \delta 2.17\left(s, 6 \mathrm{H}, \mathrm{NCH}_{3}\right), 2.22(s$, $\left.6 \mathrm{H}, \mathrm{CH}_{3}\right), 2.51\left(s, 4 \mathrm{H}, \mathrm{NCH}_{2} \mathrm{Ar}\right), 3.66\left(s, 4 \mathrm{H}, \mathrm{NCH}_{2}\right), 6.82(s, 2 \mathrm{H}, \mathrm{Ar}), 6.90(s, 2 \mathrm{H}, \mathrm{Ar}), 7.22(t, 4 \mathrm{H}$, $\mathrm{Ar}), 7.35$ ( $t, 4 \mathrm{H}, \mathrm{Ar}), 7.57$ ( $d, 4 \mathrm{H}, \mathrm{Ar}), 7.95(d, 4 \mathrm{H}, \mathrm{Ar}), 8.40(s, 2 \mathrm{H}, \mathrm{Ar})$.

$\mathrm{C}_{48} \mathrm{H}_{44} \mathrm{~N}_{2} \mathrm{O}_{2}$ - Elemental analysis (calc/found, \%): C, 84.67/84.45; H, 6.51/6.60; N, 4.11/4.02.

Cumyl-substituted ligand: ${ }^{1} \mathrm{H}$ NMR (400 MHz, $\left.\mathrm{C}_{6} \mathrm{D}_{6}, 300 \mathrm{~K}\right): \delta 1.52\left(s, 6 \mathrm{H}, \mathrm{N}-\mathrm{CH}_{3}\right), 1.78(s, 4 \mathrm{H}$, $\left.\mathrm{NCH}_{2}\right), 1.84\left(s, 12 \mathrm{H}, \mathrm{C}\left(\mathrm{CH}_{3}\right)_{2}\right), 2.28\left(s, 6 \mathrm{H}, \mathrm{CH}_{3}\right), 3.05\left(s, 4 \mathrm{H}, \mathrm{NCH}_{2} \mathrm{Ar}\right), 6.57(d, 2 \mathrm{H}, \mathrm{Ar}), 7.04(\mathrm{t}$, 2H, Ar), $7.17(t, 4 \mathrm{H}, \mathrm{Ar}), 7.29(d, 2 \mathrm{H}, \mathrm{Ar}), 7.38(d, 4 \mathrm{H}, \mathrm{Ar}), 10.19(b s, 2 \mathrm{H}, \mathrm{OH}) .{ }^{13} \mathrm{C} \mathrm{NMR}$ $\left(100 \ldots \mathrm{MHz}, \mathrm{C}_{6} \mathrm{D}_{6}, 300 \mathrm{~K}\right): \delta 21.1\left(\mathrm{CH}_{3}\right), 29.9\left(\mathrm{C}\left(\mathrm{CH}_{3}\right)_{2}\right), 41.1\left(\mathrm{~N}-\mathrm{CH}_{3}\right), 42.2\left(\mathrm{C}_{\left.\left(\mathrm{CH}_{3}\right)_{2}\right), 53.5}\right.$ $\left(\mathrm{NCH}_{2}\right), 61.9\left(\mathrm{NCH}_{2} \mathrm{Ar}\right), 122.1\left(C_{\mathrm{ipso}}\right), 125.1(C-\mathrm{H}), 126.2(C-\mathrm{H}), 126.9\left(C_{\mathrm{ipso}}\right), 127.4(C-\mathrm{H}), 127.8$ $(C-\mathrm{H}), 128.0(C-\mathrm{H}), 136.3\left(C_{\mathrm{ipso}}\right), 151.8\left(C_{\mathrm{ipso}}\right), 154.4\left(C_{\mathrm{ipso}}\right)$.

$\mathrm{C}_{38} \mathrm{H}_{48} \mathrm{~N}_{2} \mathrm{O}_{2}$ - Elemental analysis (calc/found, \%): C, 80.81/80.65; H, 8.57/8.46; N, 4.96/5.06.

\section{- Synthesis of the Zr complexes}

The synthesis was done according to the literature. 5 mmol of ligand were weighted in a Schlenk flask and dissolved in $10 \mathrm{~mL}$ of dry toluene (heating the mixture helps the dissolution of the compound). The resulting solution was added to another Schlenk flask containing a solution of 5 mmol of $\operatorname{Zr}(\text { Benzyl })_{4}$ in $10 \mathrm{~mL}$ of the same solvent, under argon atmosphere. The mixture was kept at $65{ }^{\circ} \mathrm{C}$ for $2 \mathrm{~h}$, then the solvent was evacuated to give the product as a yellow powder in quantitative yield.

Complex 3: ${ }^{1} \mathrm{H}-\mathrm{NMR}\left(400 \mathrm{MHz}, \mathrm{C}_{6} \mathrm{D}_{6}, 300 \mathrm{~K}\right): \delta 0.80\left(d, 2 \mathrm{H}, \mathrm{N}-\mathrm{CH}_{2}\right), 1.81\left(s, 6 \mathrm{H}, \mathrm{N}-\mathrm{CH}_{3}\right), 1.87$ (bd, 6H, $\mathrm{CH}_{2}$, adamantyl group), 2.11 (bd, 6H, $\mathrm{CH}_{2}$, adamantyl group), 2.30-2.45 (m, $14 \mathrm{H}, \mathrm{CH}_{3}, \mathrm{~N}-$ $\mathrm{CH}_{2} \mathrm{Ar}, \mathrm{CH}$, adamantyl group), $2.49\left(\mathrm{~m}, 12 \mathrm{H}, \mathrm{CH}_{2}\right.$, adamantyl group), $2.54\left(d, 2 \mathrm{H}, \mathrm{N}-\mathrm{CH}_{2}\right), 2.61(d$, $\left.2 \mathrm{H}, \mathrm{Zr}-\mathrm{CH}_{2}\right), 3.00\left(d, 2 \mathrm{H}, \mathrm{Zr}-\mathrm{CH}_{2}\right), 3.71\left(d, 2 \mathrm{H}, \mathrm{N}-\mathrm{CH}_{2} \mathrm{Ar}\right), 6.41(d, J=2.3 \mathrm{~Hz}, 2 \mathrm{H}, \mathrm{Ar}), 6.76(t$, $2 \mathrm{H}, \mathrm{Ar}), 7.07$ ( $t, 4 \mathrm{H}, \mathrm{Ar}), 7.21(t, 4 \mathrm{H}, \mathrm{Ar}), 7.21(d, 2 \mathrm{H}, \mathrm{Ar}) .{ }^{13} \mathrm{C} \mathrm{NMR}\left(100 \ldots . \mathrm{MHz}, \mathrm{C}_{6} \mathrm{D}_{6}, 300 \mathrm{~K}\right)$ : $\delta 21.0\left(\mathrm{CH}_{3}\right), 29.8\left(\mathrm{CH}\right.$, adamantyl group), $37.5\left(\mathrm{CH}_{2}\right.$, adamantyl group $), 41.4\left(\mathrm{CH}_{2}\right.$, adamantyl group), 42.4, $\left(C_{\mathrm{ipso}}\right.$, adamantyl group), $45.5\left(\mathrm{~N}-\mathrm{CH}_{3}\right), 52.6\left(\mathrm{NCH}_{2}\right), 63.6\left(\mathrm{NCH}_{2} \mathrm{Ar}\right), 70.6(\mathrm{ZrCH})$, $121.3(C-\mathrm{H}), 126.0\left(C_{\mathrm{ipso}}\right), 126.8(C-\mathrm{H}), 127.7\left(C_{\mathrm{ipso}}\right), 128.6(C-\mathrm{H}), 129.1(C-\mathrm{H}), 138.2\left(C_{\mathrm{ipso}}\right), 149.1$ $\left(C_{\mathrm{ipso}}\right), 157.4\left(C_{\mathrm{ipso}}\right)$. 
Complex 4: ${ }^{1} \mathrm{H}$ NMR (400 MHz, $\left.\mathrm{C}_{6} \mathrm{D}_{6}, 300 \mathrm{~K}\right): \delta 0.12\left(d, 2 \mathrm{H}, \mathrm{CH}_{2}\right), 0.89\left(d, 2 \mathrm{H}, \mathrm{CH}_{2}\right), 1.16(d, 2 \mathrm{H}$, $\left.\mathrm{CH}_{2}\right) 1.72\left(s, 6 \mathrm{H}, \mathrm{CH}_{3}\right), 2.31\left(\mathrm{~s}, 6 \mathrm{H}, \mathrm{CH}_{3}\right), 2.40\left(d, 2 \mathrm{H}, \mathrm{CH}_{2}\right), 2.88\left(d, 2 \mathrm{H}, \mathrm{CH}_{2}\right), 3.54\left(d, 2 \mathrm{H}, \mathrm{CH}_{2}\right)$, $5.74(d, 4 \mathrm{H}, \mathrm{Ar}), 6.65-6.80(\mathrm{~m}, 8 \mathrm{H}, \mathrm{Ar}), 7.15-7.50(\mathrm{~m}, 10 \mathrm{H}, \mathrm{Ar}), 7.93-8.08(\mathrm{~m}, 8 \mathrm{H}, \mathrm{Ar}), 8.36(\mathrm{~s}, 2 \mathrm{H}$, Ar).

Complex 5: ${ }^{1} \mathrm{H}-\mathrm{NMR}\left(400 \mathrm{MHz}, \mathrm{C}_{6} \mathrm{D}_{6}, 300 \mathrm{~K}\right): \delta 0.68\left(d, 2 \mathrm{H}, \mathrm{N}-\mathrm{CH}_{2}\right), 1.17\left(s, 6 \mathrm{H}, \mathrm{N}-\mathrm{CH}_{3}\right), 1.77(s$, $\left.6 \mathrm{H}, \mathrm{CH}_{3}\right), 2.03\left(s, 6 \mathrm{H}, \mathrm{CH}_{3}\right), 2.11\left(d, 2 \mathrm{H}, \mathrm{Zr}-\mathrm{CH}_{2}\right), 2.20\left(d, 2 \mathrm{H}, \mathrm{N}-\mathrm{CH}_{2} \mathrm{Ar}\right), 2.22\left(s, 6 \mathrm{H}, \mathrm{CH}_{3}\right), 2.36$ $\left(d, 2 \mathrm{H}, \mathrm{NCH}_{2}\right), 2.55\left(d, 2 \mathrm{H}, \mathrm{Zr}-\mathrm{CH}_{2}\right), 3.53\left(d, 2 \mathrm{H}, \mathrm{N}-\mathrm{CH}_{2} \mathrm{Ar}\right), 6.42(d, J=2.3 \mathrm{~Hz}, 2 \mathrm{H}, \mathrm{Ar}), 6.80(t$, $2 \mathrm{H}, \mathrm{Ar}), 6.96(d, 4 \mathrm{H}, \mathrm{Ar}), 7.04(t, 2 \mathrm{H}, \mathrm{Ar}), 7.09$ ( $t, 4 \mathrm{H}, \mathrm{Ar}), 7.19$ ( $t, 4 \mathrm{H}, \mathrm{Ar}), 7.34(d, J=2.3 \mathrm{~Hz}$, $2 \mathrm{H}, \mathrm{Ar}), 7.44(d, 4 \mathrm{H}, \mathrm{Ar}) .{ }^{13} \mathrm{C} \mathrm{NMR}\left(400 \mathrm{MHz}, \mathrm{C}_{6} \mathrm{D}_{6}, 300 \mathrm{~K}\right): \delta 21.0\left(\mathrm{CH}_{3}\right), 28.5\left(\mathrm{CH}_{3}\right), 33.3$

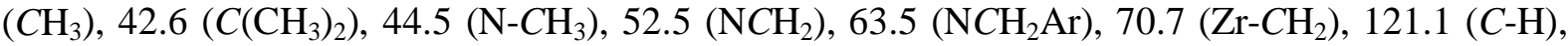
$125.6(C-\mathrm{H}), 125.9\left(C_{\mathrm{ipso}}\right), 126.9(C-\mathrm{H}), 127.1\left(C_{\mathrm{ipso}}\right), 128.3(C-\mathrm{H}), 128.4(C-\mathrm{H}), 129.4(C-\mathrm{H}), 129.5$ $(C-\mathrm{H}), 137.0\left(C_{\mathrm{ipso}}\right), 149.1\left(C_{\mathrm{ipso}}\right), 151.6\left(C_{\mathrm{ipso}}\right), 156.7\left(C_{\mathrm{ipso}}\right)$.

The solution ${ }^{1} \mathrm{H}$ NMR spectra, in particular, are diagnostic for the $C_{2}$-symmetric ligand arrangement shown in Chart 1 , as already found for the known complexes $\mathbf{1}$ and $\mathbf{2}^{5}$

\section{Synthesis and characterization of the propene homopolymers}

All polymerizations were carried out in toluene at $25^{\circ} \mathrm{C}$, following the general procedure described

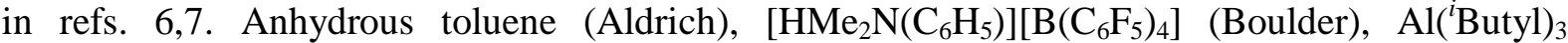

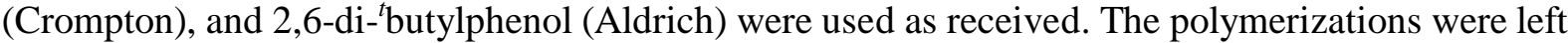
to proceed at constant monomer concentration $\left(\left[\mathrm{C}_{3} \mathrm{H}_{6}\right]=1.36 \mathrm{M}\right)$ for a desired time, after which they were quenched with acidified methanol. The polymers were coagulated with further acidified methanol, filtered, washed with methanol and vacuum-dried.

Experimental conditions: for 1 and 2, see ref. 7. For 3: toluene, $100 \mathrm{~mL} ;[\mathrm{Zr}]=4.0 \times 10^{-4} \mathrm{M}$; $[\mathrm{B}] /[\mathrm{Zr}]$ $=1.7 ;[\mathrm{Al}] /[\mathrm{Zr}]=20 ;\left[2,6-\mathrm{di}^{-}{ }^{-}\right.$Butylphenol $] /[\mathrm{Al}]=1.2$. For 4: toluene, $150 \mathrm{~mL} ;[\mathrm{Zr}]=8.0 \times 10^{-5} \mathrm{M}$; $[\mathrm{B}] /[\mathrm{Zr}]=1.7 ;[\mathrm{Al}] /[\mathrm{Zr}]=100 ;\left[2,6-\mathrm{di}^{-}{ }^{t}\right.$ Butylphenol $] /[\mathrm{Al}]=1.2$. For 5: toluene, $150 \mathrm{~mL} ;[\mathrm{Zr}]=$ $1.2 \times 10^{-4} \mathrm{M} ;[\mathrm{B}] /[\mathrm{Zr}]=1.7 ;[\mathrm{Al}] /[\mathrm{Zr}]=20 ;\left[2,6-\mathrm{di}^{-}{ }^{t}\right.$ Butylphenol $] /[\mathrm{Al}]=1.2$.

The list of polymerization experiments is given in Table $\mathrm{S} 1$.

Table S1 - List of the propene polymerization experiments.

\begin{tabular}{|l|l|l|l|l|}
\hline Catalyst & $\boldsymbol{t}_{\mathbf{p}}(\mathbf{m i n})$ & $\boldsymbol{Y}(\mathbf{g})$ & $\boldsymbol{M}_{\mathbf{n}}(\mathbf{k D a})$ & $\boldsymbol{M}_{\mathbf{w}} / \boldsymbol{M}_{\mathbf{n}}$ \\
\hline $\mathbf{2}$ & 120 & 0.09 & 4.0 & 2.0 \\
\hline $\mathbf{3}$ & 60 & 0.19 & 9.5 & 1.2 \\
\hline & 120 & 0.51 & 20 & 1.3 \\
\hline & 180 & 0.69 & 28 & 1.3 \\
\hline & 240 & 0.91 & 32 & 1.5 \\
\hline & 360 & 1.10 & 38 & 1.6 \\
\hline $\mathbf{4}$ & 120 & 1.05 & 0.8 & n.d. \\
\hline $\mathbf{5}$ & 4 & 0.12 & 11 & 1.2 \\
\hline & 8 & 0.24 & 22 & 1.3 \\
\hline & 15 & 0.45 & 37 & 1.4 \\
\hline & 30 & 0.84 & 55 & 1.5 \\
\hline
\end{tabular}


Quantitative ${ }^{1} \mathrm{H}$ and ${ }^{13} \mathrm{C}$ NMR spectra of all polymers were run with a Bruker Avance DRX 400 spectrometer, operating at $120^{\circ} \mathrm{C}$ on $30 \mathrm{mg} / \mathrm{mL}$ solutions in tetrachloroethane-1,2- $d_{2}$.

Conditions for ${ }^{1} \mathrm{H}$ NMR: $5 \mathrm{~mm}$ probe; acquisition time, $4.0 \mathrm{~s}$; relaxation delay, $5.0 \mathrm{~s}$; pulse angle, $90^{\circ}$; spectral width, $10 \mathrm{ppm} ; 128$ transients.

Conditions for ${ }^{13} \mathrm{C}$ NMR: $5 \mathrm{~mm}$ probe; acquisition time, $1.6 \mathrm{~s}$; relaxation delay, $3.0 \mathrm{~s}$; pulse angle, $90^{\circ}$; spectral width, $200 \mathrm{ppm}$; 16K transients. Broad-band proton decoupling was achieved with a modified WALTZ16 sequence (BI_WALTZ16_32 by Bruker).

It should be noted that the above conditions are adequate to avoid saturation when operating on non-deareated solutions.

Peak assignment and chain-end analysis were carried out according to the literature. ${ }^{7,9}$ In particular, the fractions of initial benzyl groups and of terminal vinylidene groups were measured by ${ }^{1} \mathrm{H} \mathrm{NMR}$, those of saturated $\left({ }^{i}\right.$ Butyl and ${ }^{n}$ Butyl) groups derived from reaction quenching with acidified methanol by ${ }^{13} \mathrm{C}$ NMR. The values of $M_{\mathrm{n}}$ for the polymers prepared with catalysts $\mathbf{2 - 5}$ are given in Table S1.

\section{- Other characterizations}

Molecular mass distributions were measured by Gel Permeation Chromatography (GPC), using a Polymer Laboratories GPC220 apparatus equipped with a Viscotek 220R viscosimeter, on polymer solutions in $1,2,4$-trichlorobenzene at $135^{\circ} \mathrm{C}$. The values of $M_{\mathrm{w}} / M_{\mathrm{n}}$ are reported in the last column of Table S1.

Melting parameters (reported in the text) were determined by Differential Scanning Calorimetry with a Perkin Elmer DSC-7 apparatus, at the scanning rate of $10^{\circ} \mathrm{C} \mathrm{min}^{-1}$, on the $2^{\text {nd }}$ heating scan.

\section{- Kinetic elaboration of the polymerization results}

The NMR values of $M_{\mathrm{n}}$ as a function of the polymerization time, $t_{\mathrm{p}}$ (Table $\mathrm{S} 1$ ) for polypropylene samples prepared with catalysts $\mathbf{3}$ and $\mathbf{5}$ were interpolated according to the following equation (Eq 1 of ref. 7):

$$
1 / P_{\mathrm{n}}=M_{1} / M_{\mathrm{n}}=f_{\mathrm{t}} /\left(k_{\mathrm{p}}[M]\right)+1 /\left(k_{\mathrm{p}}[M] t_{\mathrm{p}}\right)
$$

with $P_{\mathrm{n}}=$ number-average degree of polymerization; $M_{1}=$ molar mass of the monomer; $[M]=$ monomer concentration; $k_{\mathrm{p}}=$ kinetic constant of chain propagation; $f_{\mathrm{t}}=$ frequency of chain transfer. For polymers prepared with catalysts $\mathbf{2}$ and $\mathbf{4}$, the average molecular mass and the stereoregularity were too low for meaningful measurements and elaborations.

\section{Synthesis and characterization of iPP-block-PE}

The synthesis was carried out in a $250 \mathrm{~mL}$ magnetically stirred jacketted Pyrex reactor with three necks; one was serum-capped, another was connected to a Schlenk manifold, the last one was fitted with a cannula allowing to introduce a monomer or an inert gas directly in the liquid phase. The reactor was charged under argon with $100 \mathrm{~mL}$ of dry toluene, containing $2.0 \mathrm{~mL}$ of MAO (Crompton, $10 \% \mathrm{w} / \mathrm{w}$ solution in toluene) and $370 \mathrm{mg}$ of 2,6-di-butylphenol (Aldrich). After 30 min at $25^{\circ} \mathrm{C}, 5 \mathrm{~mL}$ of the liquid phase were taken out, and used to dissolve $16 \mathrm{mg}$ of $\mathbf{3}$ in a glass vial. The reactor was then saturated with ethene at the partial pressure of $1.7 \mathrm{bar}$, and the ethene homopolymerization step started by injecting the catalyst solution through the serum cap. After 3.0 min, the ethene feed was interrupted, and the reactor was evacuated and flushed with argon several times in order to remove all unreacted ethene (overall purging time, $1 \mathrm{~min}$ ). After a last evacuation, 
the liquid phase was saturated with propene at a partial pressure of 2.0 bar, and propene homopolymerization left to proceed at constant pressure for $60 \mathrm{~min}$, after which the reaction was quenched with $5 \mathrm{~mL}$ of methanol/ $\mathrm{HCl}(\mathrm{aq}$, conc.) $(95 / 5 \mathrm{v} / \mathrm{v})$. The polymer was then coagulated with excess methanol/ $\mathrm{HCl}$, filtered, washed with more methanol and vacuum-dried (yield, $0.24 \mathrm{~g}$ ).

The sample was characterized by ${ }^{1} \mathrm{H}$ and ${ }^{13} \mathrm{C}$ NMR, GPC, and DSC as described for the propene homopolymers. The numerical data have been reported in the text. The GPC trace is shown in Figure S1. The DSC trace ( $2^{\text {nd }}$ heating scan) is shown in Figure S2.

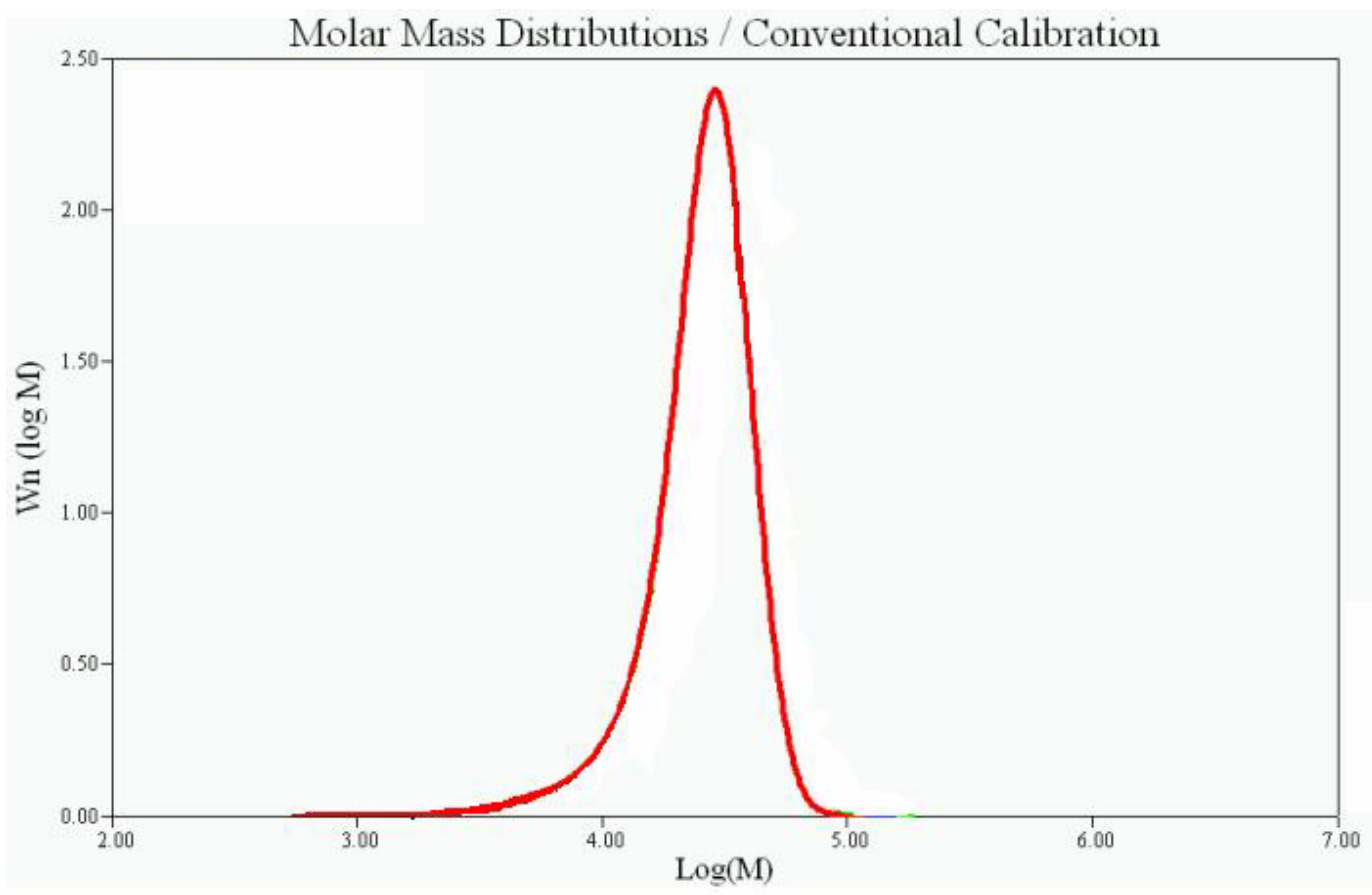

Figure S1. GPC trace of the sample of iPP-block-PE. 


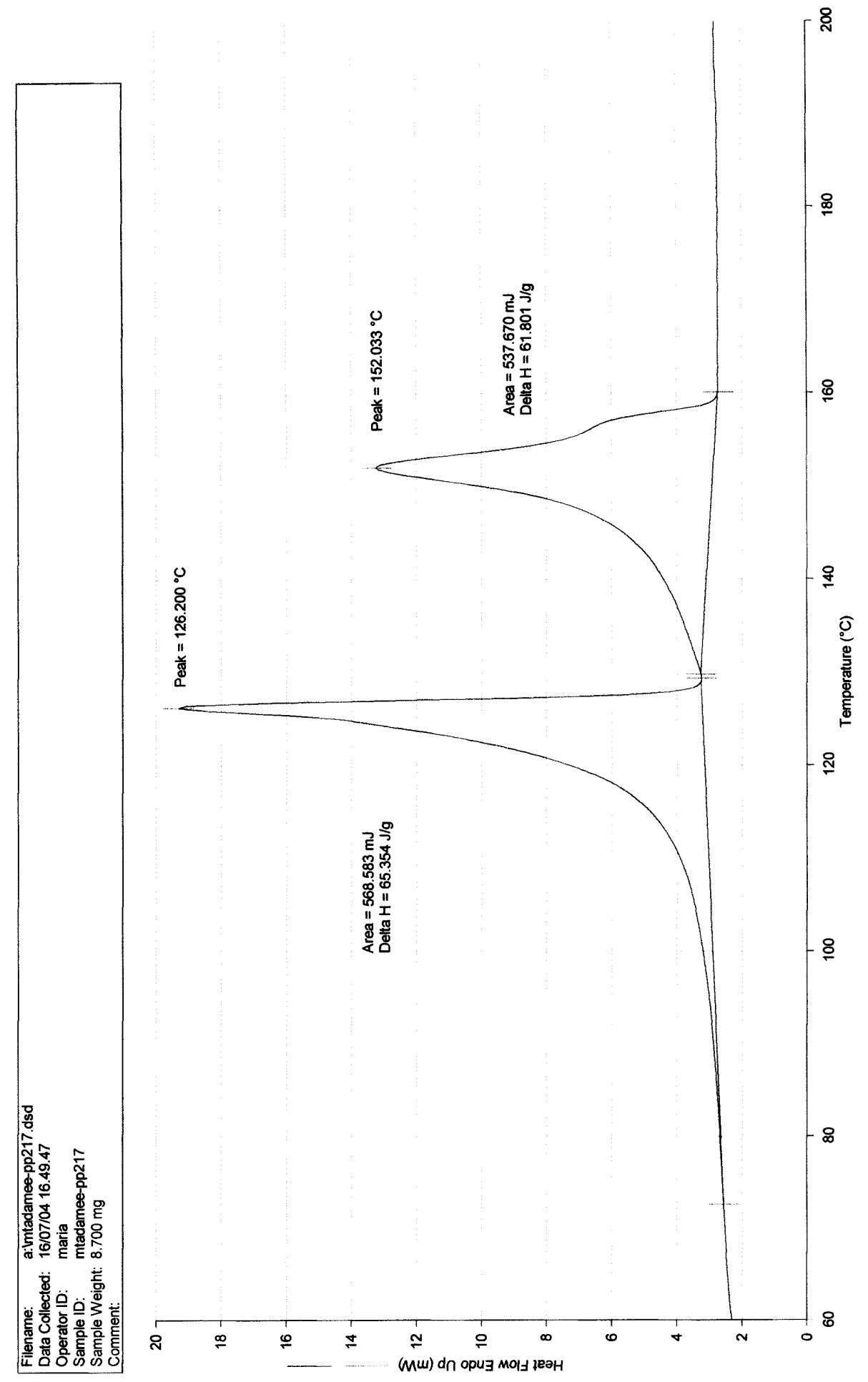

Figure S2. $2^{\text {nd }}$ DSC heating scan of the sample of iPP-block-PE. 


\section{Computational Details}

Stationary points on the potential energy surface were calculated with the Amsterdam Density Functional (ADF) program system, ${ }^{\mathrm{S} 1}$ developed by Baerends et al. ${ }^{\mathrm{S} 2 \mathrm{~S} 3}$ The electronic configuration of the molecular systems were described by a triple- $\zeta$ STO basis set on zirconium for $4 s, 4 p, 4 d$, $5 s, 5 p$ (ADF basis set IV). Double- $\zeta$ STO basis sets were used for oxygen, nitrogen and carbon $(2 s$, $2 p$ ) and hydrogen ( $1 s$ ), augmented with a single $3 d, 3 d$, and $2 p$ function, respectively (ADF basis set III). ${ }^{1}$ The inner shells on zirconium ( $\left.3 \mathrm{~d}\right)$, oxygen, nitrogen and carbon $(1 s)$, were treated within the frozen core approximation. Energies and geometries were evaluated by using the local exchangecorrelation potential by Vosko et $a l,{ }^{\mathrm{S} 4}$ augmented in a self-consistent manner with Becke's ${ }^{5}$ exchange gradient correction and Perdew's ${ }^{\mathrm{S}, \mathrm{S7}}$ correlation gradient correction.

The partitioning of the systems into QM and MM parts only involved the R substituents on the skeleton of amine bis(phenolate) ligand (see Figure S3).

The ADF program was modified by Cavallo ${ }^{\mathrm{S} 8}$ to include standard Molecular Mechanics force fields in such a way that the QM and MM parts are coupled self-consistently. ${ }^{\mathrm{S} 9}$ In the QM/MM optimizations, the ratio between the $\mathrm{C}-\mathrm{C}$ bonds crossing the $\mathrm{QM} / \mathrm{MM}$ border, and the corresponding optimized $\mathrm{C}-\mathrm{H}$ distances was fixed equal to 1.35 , in order to reproduce the corresponding full-QM bond lengths. A more detailed description of the coupling scheme, as well as further comments on the methodology, can be found in previous papers. ${ }^{\mathrm{S}, \mathrm{S} 10}$ The CHARMM force field ${ }^{\mathrm{S} 11}$ was used for the MM potentials, except for $\mathrm{Zr}$ which was treated with the UFF force field. ${ }^{\text {S12 }}$ To eliminate spurious stabilizations from the long-range attractive part of the LennardJones potential, ${ }^{\mathrm{S} 10, \mathrm{~S} 13}$ we used an exponential expression fitted to the repulsive part of the LennardJones potential. ${ }^{\mathrm{S} 10, \mathrm{~S} 14-\mathrm{S} 16}$ Transition state geometries were approached by a linear-transit procedure, using the distance between the $\mathrm{C}$ (propene) and $\mathrm{C}$ (growing chain) atoms which are going to form the new $\mathrm{C}-\mathrm{C}$ bond as reaction coordinate, while optimizing all other degrees of freedom. Consistently, in the case of termination reaction we used the distance between the $\mathrm{C}$ (propene) and $\mathrm{H}$ (growing chain) atoms which are going to form the new $\mathrm{C}-\mathrm{H}$ bond. Full transition state searches were started from the geometries corresponding to maxima along the linear-transit curves.

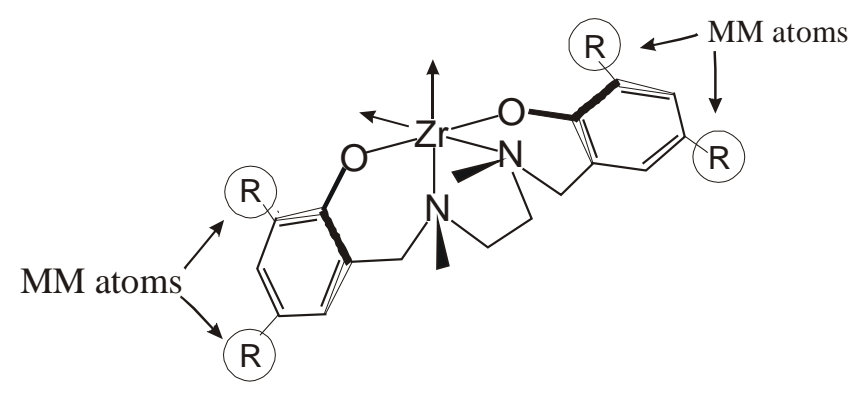

Figure S3. Partitioning between QM and MM treatment for the systems of Chart 1. 


\section{Additional References}

(S1) ADF 2.3.0, Users Manual, Vrije Universiteit Amsterdam: Amsterdam, The Netherlands, 1996.

(S2) Baerends, E. J.; Ellis, D. E.; Ros, P. Chem. Phys. 1973, 2, 41.

(S3) te Velde, G.; Baerends, E. J. J. Comp. Phys. 1992, 99, 84.

(S4) Vosko, S. H.; Wilk, L.; Nusair, M. Can. J. Phys. 1980, 58, 1200.

(S5) Becke, A. Phys. Rev. A 1988, 38, 3098.

(S6) Perdew, J. P. Phys. Rev. B 1986, 33, 8822.

(S7) Perdew, J. P. Phys. Rev. B 1986, 34, 7406.

(S8) Woo, T. K.; Cavallo, L.; Ziegler, T. Theor. Chem. Acc. 1998, 100, 307.

(S9) Maseras, F.; Morokuma, K. J. Comput. Chem. 1995, 16, 1170.

(S10) Cavallo, L.; Woo, T. K.; Ziegler, T. Can. J. Chem. 1998, 76, 1457.

(S11) Brooks, B. R.; Bruccoleri, R. E.; Olafson, B. D.; States, D. J.; Swaminathan, S.; Karplus, M. J. Comput. Chem. 1983, 4, 187.

(S12) Rappé, A. K.; Casewit, C. J.; Colwell, K. S.; Goddard III, W. A.; Shiff, W. M. J. Am. Chem. Soc. 1992, 114, 10024.

(S13) Sauers, R. R. J. Chem. Educ. 1996, 73, 1996.

(S14) Lee, K. J.; Brown, T. L. Inorg. Chem. 1992, 31, 289.

(S15) Woo, T. K.; Ziegler, T. Inorg. Chem. 1994, 33, 1857.

(S16) Guerra, G.; Cavallo, L.; Corradini, P.; Longo, P.; Resconi, L. J. Am. Chem. Soc. 1997, 119, 4394. 